\title{
Comparison of the Ahmed glaucoma valve with the Baerveldt glaucoma implant: a meta-analysis
}

\author{
Yi-Wen Wang ${ }^{1}$, Ping-Bao Wang ${ }^{1}$, Chao Zeng ${ }^{2}$ and Xiao-Bo Xia ${ }^{1 *}$
}

\begin{abstract}
Background: This study aims to compare the efficacy and safety of the Ahmed glaucoma valve (AGV) with the Baerveldt glaucoma implant (BGI) in glaucoma patients.

Methods: Databases were searched to identify studies that met pre-stated inclusion criteria, involving randomized controlled clinical trials (RCTs) and non-randomized controlled clinical trials. Treatment effect was analyzed using a random-effect model.

Results: Ten controlled clinical trials (1048 eyes) were analyzed, involving two RCTs and eight retrospective comparative studies. Short-term results (6-18 months) and long-term results (>18 months) were analyzed separately. There was no significant difference in the success rate for short-term follow-up between the AGV and BGI groups (5studies, 714 eyes, odds ratio [OR]: 0.97; $95 \%$ confidence interval [Cl]: 0.56, 1.66; $P=0.90$ ). For long-term pooled results (7studies, 835 eyes), the success rate of AGVs was lower than that of BGls (OR: 0.73; $95 \%$ Cl: 0.54, 0.99, $P=0.04$ ), However, subgroup and sensitivity analyses did not show a significant difference in the success rate between the two groups $(P \geq 0.05)$. The AGV group had a higher mean intraocular pressure than the BGl group in short-term (6 studies, 685 eyes, weighted mean difference [WMD]: $2.12 \mathrm{mmHg} ; 95 \% \mathrm{Cl}$ : 0.72-3.52; $P<0.05)$ and long-term pooled results (7 studies, 659 eyes, WMD: $1.85 \mathrm{mmHg} ; 95 \% \mathrm{Cl}: 0.43,3.28 ; P=0.01$ ). The BGl group required fewer glaucoma medications after implantation than the AGV group in two follow-up periods (all $P<0.05$ ). The AGV was found to be associated with a significantly lower frequency of total complications (8 studies, 971 eyes, OR: 0.67; 95 \% Cl: 0.50-0.90; $P=0.007$ ) and severe complications (8 studies, 971 eyes, OR: $0.57 ; 95 \% \mathrm{Cl}: 0.36-0.91 ; P=0.02$ ) than the BGl.
\end{abstract}

Conclusions: The study showed no significant difference in success rate between the two groups. The BGI was more effective for control of intraocular pressure and required fewer medications than the AGV, but the AGV had lower incidence of total and severe complications than the BGI.

Keywords: Glaucoma, Ahmed glaucoma valve implantation, Baerveldt glaucoma implant, Meta-analysis

\section{Background}

Glaucoma is the leading cause of irreversible blindness worldwide. Because conventional trabeculectomy and glaucoma medicines result in low success rates $[1,2]$, glaucoma drainage implants (GDIs) have been used with increasing frequency in the management of refractory glaucoma. In 1969, Molteno [3] invented the first of many glaucoma implants. The Ahmed glaucoma valve (AGV)

\footnotetext{
*Correspondence: xbxia21@163.com

'Department of Ophthalmology, Xiangya Hospital, Central South University, \#87 Xiangya Road, Changsha, Hunan 410008, China

Full list of author information is available at the end of the article
}

and Baerveldt glaucoma implant (BGI) are currently two of the most commonly used implants for aqueous drainage. Both of them reduce intraocular pressure (IOP) by draining aqueous humor through a tube to a subconjunctival end plate. The AGV contains a one-way valve, which opens in response to a pressure increase in the anterior chamber, and thus helps to reduce the risk of complications, such as hypotony $[4,5]$. The BGI, which has no valves, is available in three models according to different surface areas of the end plate $\left(500 \mathrm{~mm}^{2}, 350 \mathrm{~mm}^{2}\right.$, and $250 \mathrm{~mm}^{2}$ ). A review by Patel et al. [6] concluded that the AGV has similar success rates and IOP-lowering effects as 
the BGI. However, a study by Budenz et al. showed that BGI implants produce greater long-term reduction in IOP [7]. Therefore, in the present study, we aimed to determine the efficacy and safety of these two devices for treating patients with glaucoma.

\section{Methods}

The study was approved by the ethics committee at Xiangya Hospital, Central South University, and was conducted in accordance with the Protocol of Helsinki.

\section{Search strategy and trial selection}

We searched PubMed, EMBASE, and Cochrane Controlled Trials Register databases (up to February, 2015) using the following search terms: "glaucoma," "ocular hypertension," "intraocular pressure," "Ahmed," and "Baerveldt." The publication dates and languages were not limited, and we identified references of retrieved articles and reviews (Additional file 1). Screening of the articles was performed independently by two reviewers.
Studies meeting the following criteria were considered eligible for our meta-analyses: (1) a study design involving comparative clinical trials, including randomized controlled clinical trials (RCTs) and non-randomized controlled clinical trials (non-RCTs); (2) eyes diagnosed with glaucoma undergoing the AGV or BGI; and (3) at least one of the following reported outcomes: success rate, number of glaucoma medicines, mean IOP, and occurrence of adverse events. Exclusion criteria were as follows: (1) case reports, reviews, animal trials, and letters to the editor; (2) studies involving surgery combined with other glaucoma surgeries; (3) studies that implanted two or more GDIs; and (4) studies involving eyes undergoing GDI replacement surgery.

\section{Data extraction and qualitative assessment}

Article quality and extracted data were assessed by two independent readers. Any disagreements were resolved by discussion. The information collected included the first author, publication year, study design, participants

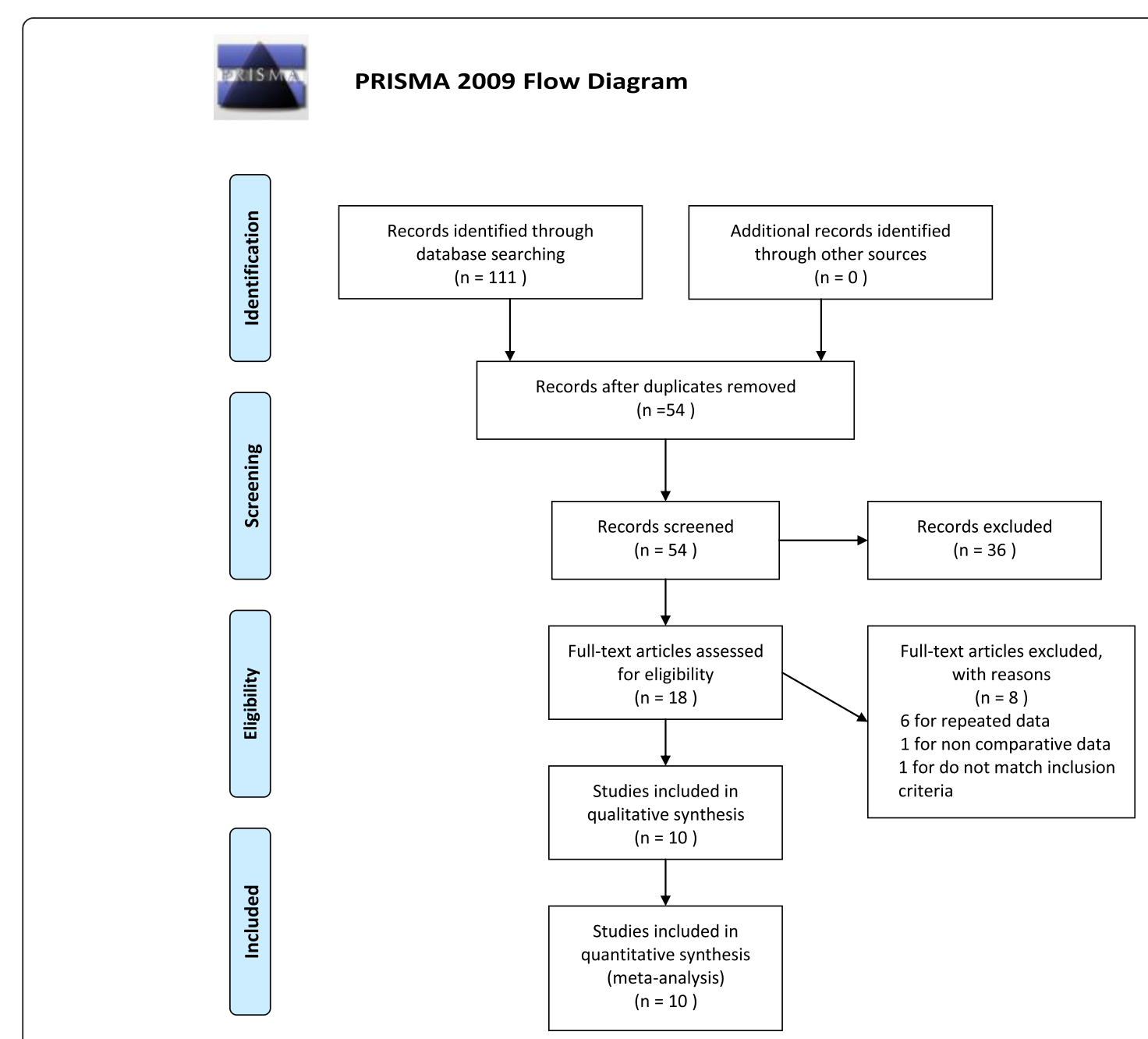

Fig. 1 Flow diagram for the selection of included trials 
Table 1 Baseline characteristics of eligible clinical trials

\begin{tabular}{|c|c|c|c|c|c|c|c|c|c|c|}
\hline Author (Year) & Design & Inclusion criteria & $\begin{array}{l}\text { Number } \\
\text { of eyes }\end{array}$ & $\begin{array}{l}\text { Sex } \\
(M / F)\end{array}$ & Age (year) & $\begin{array}{l}\text { Models of } \\
\text { AGV }\end{array}$ & $\begin{array}{l}\text { Models of } \\
\text { BGl }\end{array}$ & $\begin{array}{l}\text { IOP (mmHg) } \\
\text { Standards of } \\
\text { Success }\end{array}$ & $\begin{array}{l}\text { Follow-up duration } \\
\text { (months) }\end{array}$ & $\begin{array}{l}\text { Baseline IOP } \\
(\mathrm{mmHg})\end{array}$ \\
\hline \multirow[t]{2}{*}{ Budenz DL (2015) } & \multirow[t]{2}{*}{$\mathrm{RCT}$} & \multirow[t]{2}{*}{$>18 y$} & A:143 & $A: 73 / 70$ & A:65.4 \pm 12.8 & \multirow[t]{2}{*}{ FP7 } & \multirow[t]{2}{*}{350} & \multirow{2}{*}{$\begin{array}{l}5 \leq 1 \mathrm{OP} \leq 21 \text { and } \\
\geq 20 \% \text { reduction }\end{array}$} & \multirow[t]{2}{*}{60} & $A: 31.2 \pm 11.2$ \\
\hline & & & B:133 & B:70/63 & $B: 62.2 \pm 14.2$ & & & & & B:31.8 \pm 12.5 \\
\hline \multirow[t]{2}{*}{ Christakis PG (2013) } & \multirow[t]{2}{*}{$\mathrm{RCT}$} & \multirow[t]{2}{*}{$>18 y$} & A:124 & $A: 65 / 59$ & $A: 65 \pm 17$ & \multirow[t]{2}{*}{ FP7 } & \multirow[t]{2}{*}{350} & \multirow{2}{*}{$\begin{array}{l}5 \leq 1 \mathrm{OP} \leq 21 * \text { and } \\
\geq 20 \% \text { reduction }\end{array}$} & \multirow[t]{2}{*}{36} & A:31.1 \pm 10.5 \\
\hline & & & B:114 & B:41/73 & $B: 67 \pm 15$ & & & & & B:31.7 \pm 11.1 \\
\hline \multirow[t]{2}{*}{ El Gendy NM (2012) } & \multirow[t]{2}{*}{ Retro } & \multirow[t]{2}{*}{$<18 y$} & $A: 11$ & $A: 4 / 7$ & A:6.7 & \multirow[t]{2}{*}{ S2 } & \multirow[t]{2}{*}{250} & \multirow[t]{2}{*}{$8 \leq 1 \mathrm{OP} \leq 24$} & $A: 32.4$ & A:39.8 \pm 6.2 \\
\hline & & & $B: 20$ & B:12/8 & B:5.4 & & & & B:45.6 & $B: 33.8 \pm 5.7$ \\
\hline \multirow[t]{2}{*}{ Goulet RJ (2008) } & \multirow[t]{2}{*}{ Retro } & \multirow[t]{2}{*}{ All ages } & $A: 59$ & A:25/34 & A:66.3 \pm 15.14 & \multirow[t]{2}{*}{ S2 } & \multirow[t]{2}{*}{250} & \multirow{2}{*}{$\begin{array}{l}5<1 \mathrm{OP}<22 \text { and } \\
\geq 20 \% \text { reduction }\end{array}$} & $A: 20.0 \pm 26.7$ & A: $35.3 \pm 13.4$ \\
\hline & & & B:133 & B:64/69 & B:64.3 \pm 16.9 & & & & B:22.9 \pm 19.9 & B:35.3 \pm 12.9 \\
\hline \multirow[t]{2}{*}{ Tsai JC (2006) } & \multirow[t]{2}{*}{ Retro } & \multirow[t]{2}{*}{$>18 y$} & A:48 & $A: 18 / 30$ & A:69.2 & \multirow[t]{2}{*}{ S2 } & \multirow[t]{2}{*}{250 and 350} & \multirow{2}{*}{$\begin{array}{l}6 \leq 1 \mathrm{OP} \leq 21 \text { and } \\
\geq 20 \% \text { reduction }\end{array}$} & \multirow[t]{2}{*}{48} & A:38.5 \\
\hline & & & $\mathrm{B}: 70$ & $B: 36 / 34$ & B:62.3 & & & & & B:34.6 \\
\hline Tesser R (2005) & Retro & $<18 y$, concurrent & $A: 3$ & ND & 7.6 & S2 & 250 and 350 & $\mathrm{IOP} \leq 22$ & 21 & $A: 35 \pm 4.6$ \\
\hline & & $\begin{array}{l}\text { primary or secondary } \\
\text { IOL implantation }\end{array}$ & B:6 & & & & & & & $\mathrm{B}: 31.3 \pm 0.8$ \\
\hline Chung AN (2004) & Retro & $>18 y$, concurrent Phaco & $A: 16$ & $15 / 17$ & $58 \pm 16$ & ND & 350 & $6 \leq 1 \mathrm{OP} \leq 21$ & $13 \pm 5$ & A:26.2 \pm 13.4 \\
\hline & & and IOL Implant & B:16 & & & & & & & B:29.7 \pm 13.4 \\
\hline Syed HM (2004) & Case control & All ages, Baerveldt & $A: 32$ & $A: 20 / 12$ & $A: 58 \pm 24$ & Polypropylene & 350 & $5<1 \mathrm{OP}<22$ and & $8-16$ & $A: 30.69 \pm 10.28$ \\
\hline & & $\begin{array}{l}\text { matched case by case } \\
\text { with Ahmed valve } \\
\text { implantation }\end{array}$ & B:32 & B:13/19 & $B: 61 \pm 23$ & & & $230 \%$ reauction & & B:30.09 \pm 9.17 \\
\hline Wang JC (2004) & Retro & All ages & $A: 18$ & $A: 10 / 8$ & A: $60.0 \pm 18.2$ & S2 & 250 & $1 \mathrm{IP}<22$ & $A: 22.2 \pm 9.2$ & A:43.7 \pm 9.3 \\
\hline & & & B:24 & B:15/8 & B: $48.1 \pm 23.2$ & & & & $\mathrm{~B}: 22.8 \pm 8.7$ & B: $40.1 \pm 13.8$ \\
\hline Beck AD (2003) & Retro & $<2 y$ & $A: 32$ & ND & $7 m o n \pm 5.1$ & $\mathrm{~S} 2$ and $\mathrm{S} 3$ & 250 and 350 & $1 \mathrm{OP}<23$ & $A: 33.0 \pm 25.5$ & $A: 32.2 \pm 7.0$ \\
\hline & & & B:14 & & & & & & $B: 24.9 \pm 12.9$ & $B: 33.5 \pm 5.6$ \\
\hline
\end{tabular}


(number, age, and sex), GDI model, follow-up time, and baseline IOP.

Quality assessment of the RCTs was performed using Cochrane Collaboration's tool to assess risks of bias [8], including selection bias, performance bias, detection bias, attrition bias, reporting bias, and other biases. Every bias item was associated with a level of risk (high, low, or unclear). The quality of non-RCTs was evaluated according to an assessment system for non-randomized studies reported by the Chinese Cochrane Centre [9]. The checklist of the system consisted of six items: methods of grouping, methods of blinding, inclusion of all patients, baselines, standards of diagnosis, and control of confounding factors. Because bias of selective reporting was not included in this system, we added the item in assessment. Each item was worth $0-2$ points, with a maximum total of 14 points. The overall quality of evidence was evaluated using the GRADE system (performed by GRADEpro3.6, http://cebgrade.mcmaster.ca/Introduction/index.html) [10].

\section{Statistical analysis}

Data analysis was performed using Review Manager 5 software (RevMan 5, The Cochrane Collaboration, Oxford, UK). For dichotomous outcomes, odds ratios (ORs) were calculated. For continuous outcomes, the mean and SD were used to calculate weighted mean differences (WMDs). The heterogeneity of effect size was evaluated by the chi-square test. $\mathrm{I}^{2}$ statistics and $P$ value were calculated. $P>0.1$ was considered as no significant heterogeneity. Results were pooled using the random-effect model in a meta-analysis. To evaluate publication bias, we performed Begg's test [11] and inspected funnel plots. $P<0.05$ was considered statistically significant. A sensitivity analysis was conducted to confirm the stability of the meta-analysis results. PRISMA checklist for this meta-analysis can be obtained in Additional file 2 .

\section{Results}

The study identification process is illustrated in Fig. 1. A total of 54 articles were identified by search strategies after duplicates were removed. No study reporting other outcomes was found in comparing the two interventions. Ten articles that enrolled a total of 1048 eyes (486 in the AGV group and 562 in the BGI group) were included in our meta-analysis [7, 12-20]. Two of them were RCTs and the remaining studies were retrospective comparative studies. Two of the included retrospective comparative studies (Tesser et al. [16] and Chung et al. [17]) concurrently performed lens extraction (phacoemulsification or extracapsular cataract removal) with intraocular lens (IOL) implantation or secondary IOL implantation. Although we did not limit the types of glaucoma, most patients undergoing implantation were diagnosed with refractory glaucoma. The mean ages ranged from 5 months to 80 years. The male to female sex ratio ranged from 0.57 to 1.67 in the AGV group, and 0.6 to 1.88 in the BGI group. The follow-up time ranged from 8 months to 5 years. Study characteristics are listed in Table 1.

Qualitative assessment of these studies is summarized in Tables 2 and 3. Chung et al's study [17] was assessed with a low quality score (score 5 ). Tesser et al's study [16] had an inadequate sample size. Both of these studies concurrently performed lens-related surgeries. To eliminate potential heterogeneity, we performed a sensitivity analysis after removal of data from these two articles.

For studies with results available at different time points, we analyzed short-term results and long-term results separately. For analysis of short-term results, we pooled data during the mean follow-up times between 6 months to 18 months. Data at 1-year time points in long-term studies were also included. Data at final follow-ups of studies with mean follow-up times $>18$ months were analyzed for long-term results. Subgroup analyses were performed based on patients' age (children and adults subgroups) and the study design (RCT and non-RCT subgroups). The boundary of age between the children subgroup and adult subgroup was 18 years.

\section{Success rate}

The definition of success rate was consistent with the original studies with one exception. Christakis et al. [12] reported three sets of results according to different IOP criteria ( $\leq 14 \mathrm{mmHg}, 18 \mathrm{mmHg}$, or $21 \mathrm{mmHg}$ ). We adopted results using IOP criteria less than $21 \mathrm{mmHg}$ in this article. For the rest of the studies, the crude data was pooled directly based on their original definition of success rate. Five studies (714 eyes) were included in the short-term analyses, and seven studies (835 eyes) were included in the long-term analyses. In short-term followup, the success rate in the AGV group was $78.6 \%$ and that in the BGI group was $79.7 \%$. No significant difference was observed between the two groups (OR: 0.97;

Table 2 List of biases in RCTs

\begin{tabular}{|c|c|c|c|c|c|c|c|}
\hline & $\begin{array}{l}\text { Random } \\
\text { sequence } \\
\text { generation }\end{array}$ & $\begin{array}{l}\text { Allocation } \\
\text { concealment }\end{array}$ & $\begin{array}{l}\text { Blinding of } \\
\text { participants } \\
\text { and personnel }\end{array}$ & $\begin{array}{l}\text { Blinding of } \\
\text { outcome } \\
\text { assessment }\end{array}$ & $\begin{array}{l}\text { Incomplete } \\
\text { outcome data }\end{array}$ & $\begin{array}{l}\text { Selective } \\
\text { reporting }\end{array}$ & Other bias \\
\hline Budenz DL (2015) & low risk & low risk & high risk & high risk & low risk & low risk & / \\
\hline Christakis PG (2013) & low risk & low risk & high risk & high risk & low risk & low risk & / \\
\hline
\end{tabular}


Table 3 Quality assessment of non-RCTs

\begin{tabular}{|c|c|c|c|c|c|c|c|c|}
\hline & $\begin{array}{l}\text { Methods } \\
\text { of grouping }\end{array}$ & $\begin{array}{l}\text { Methods } \\
\text { of blinding }\end{array}$ & $\begin{array}{l}\text { Inclusion of } \\
\text { all patients }\end{array}$ & Baselines & $\begin{array}{l}\text { Standards } \\
\text { of diagnosis }\end{array}$ & $\begin{array}{l}\text { Control of } \\
\text { confounding factors }\end{array}$ & $\begin{array}{l}\text { Selective } \\
\text { reporting }\end{array}$ & Total score \\
\hline El Gendy NM (2012) & 0 & 0 & 0 & 2 & 2 & 1 & 2 & 7 \\
\hline Goulet RJ (2008) & 0 & 0 & 2 & 2 & 2 & 2 & 2 & 10 \\
\hline Tsai JC (2006) & 0 & 0 & 2 & 2 & 2 & 1 & 0 & 7 \\
\hline Tesser R (2005) & 0 & 0 & 2 & 2 & 2 & 0 & 2 & 8 \\
\hline Chung AN (2004) & 0 & 0 & 0 & 1 & 2 & 0 & 2 & 5 \\
\hline Syed HM (2004) & 0 & 0 & 1 & 2 & 2 & 1 & 1 & 7 \\
\hline Wang JC (2004) & 0 & 0 & 1 & 2 & 2 & 0 & 2 & 7 \\
\hline Beck AD (2003) & 0 & 0 & 2 & 1 & 2 & 0 & 1 & 6 \\
\hline
\end{tabular}

$95 \%$ confidence interval $[\mathrm{CI}]: 0.56,1.66 ; P=0.90$ ) (Fig. 2). Sensitivity analyses (4 studies, 682 eyes) yielded a similar result (OR: 0.87; $95 \%$ CI: $0.56,1.35 ; P=0.53$ ). In long-term follow-up, the success rate in the AGV group was $59.2 \%$ and that in the BGI group was $68.4 \%$. Pooled results (OR, 0.73; 95 \% CI: 0.54, 0.99) showed a P-value of 0.04 , slightly less than the 0.05 threshold (Fig. 3). Therefore, there are some evidence indicate that the success rate for the AGV group was significantly lower than BGI group in long-tern follow-up. Moreover, sensitivity analyses ( 6 studies, 826 eyes) showed no significant difference between the two groups (OR: 0.74; $95 \%$ CI: $0.55,1.00 ; P=0.05)$. A pooled result from three studies (632 eyes) showed that the number of reoperations for glaucoma in the AGV group was significantly higher than that for the BGI group (OR: 2.70; 95 \% CI: 1.54, 4.74; $P=0.0005$ ).

A summary of subgroup and sensitivity analyses is shown in Table 4. Although the BGI group showed a higher success rate in total results for long-term followups than the AGV group, subgroup and sensitivity analyses did not show a significant difference between the two groups. The pooled results of the RCT and non-RCT subgroups showed no evidence of statistically significant differences between the two groups for short- and longterm follow-ups. Data from two studies (40 eyes) that focused on children were pooled in long-term follow-up. We found no significant difference in success rate was been observed (OR: 0.96; $95 \%$ CI: 0.04, 21.88, $P=0.98$ ) and there was high heterogeneity $\left(\mathrm{I}^{2}=64 \%, P=0.1\right)$. The large CI suggests that this result may not be reliable. The pooled results of the adult subgroup showed that there was no significant differences in two follow-up times (Table 4). The heterogeneity test showed a lack of significant heterogeneity for total and sensitivity analyses, and RCT, Non-RCT subgroup $\left(\mathrm{I}^{2}<50 \%, P>0.1\right)$.

\section{IOP}

We pooled the mean IOPs for the two groups because all articles reported the absolute IOP after the operation. Detail data of total and subgroup analyses are shown in Table 5. In short-term follow-up, the difference in the pooled mean IOP from six studies (685 eyes) for the AGV group compared with the BGI group was 2.12 $\mathrm{mmHg}$ (95 \% CI: $0.72,3.52)$, which was statistically significant $(P=0.003$, Fig. 4$)$. Significant heterogeneity was observed $\left(\mathrm{I}^{2}=49 \%, P=0.08\right)$. Sensitivity analyses showed that the overall WMD did not substantially change, and no evidence of significant heterogeneity was observed $\left(\mathrm{I}^{2}=0 \%, P=0.6\right)$. In long-term follow-up, the difference in the pooled mean IOP from seven studies (659 eyes) for the AGV group compared with the BGI

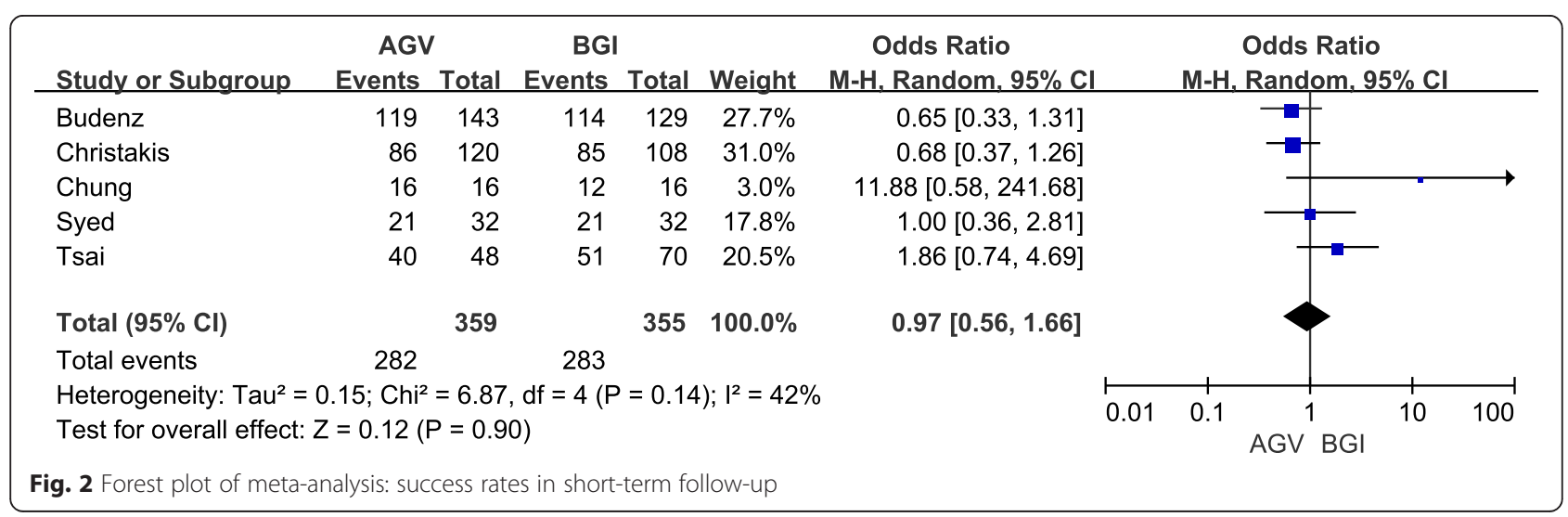




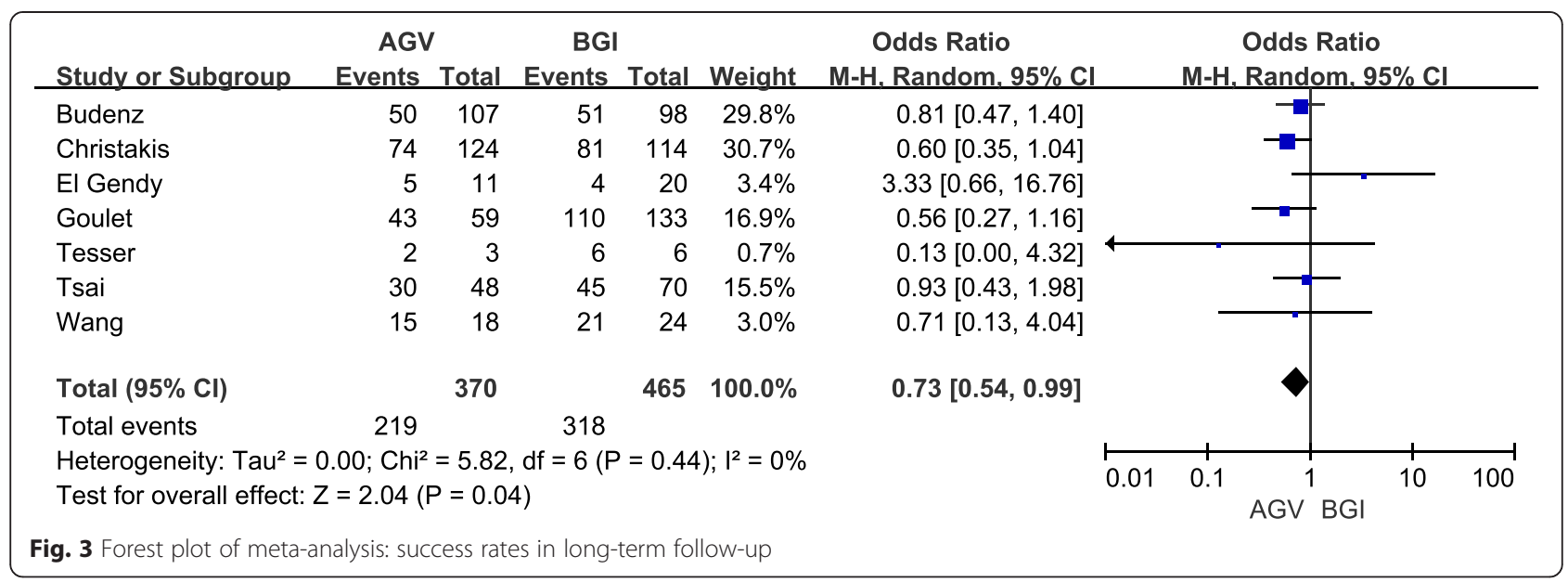

group was $1.85 \mathrm{mmHg}$ (95\% CI: 0.43, 3.28), which was statistically significant $(P=0.01$, Fig. 5). However, significant heterogeneity was observed $\left(\mathrm{I}^{2}=44 \%, P=0.1\right)$. The result of Sensitivity analyses (excluded two studies) consisted with the total group (included all eligible studies), but heterogeneity was still significant $\left(\mathrm{I}^{2}=53 \%, P=0.06\right)$.

The pooled results from the RCT group were similar to the total group in short-and long-term follow-ups, with no statistically significant heterogeneity. No difference in IOP was observed between the BGI and AGV groups in the non-RCT subgroup in short-term followup (4 studies, 208 eyes, WMD: 1.68; 95 \% CI:-1.27, 4.63; $P=0.26$ ) and long-term follow-up (5 studies, 319 eyes, WMD: $2.18,95 \% \mathrm{CI}$ : $-0.91,5.27 ; P=0.17)$. Significant heterogeneity was observed in the non-RCT group $(P$ $<0.1)$. The results of the children subgroup analysis consisted with the total group. For short-term followup, adult subgroup analysis included two RCTs and one non-RCT study (total 509 eyes). There was no significant difference in IOP between the two groups (WMD: 1.44, $95 \% \mathrm{CI}:-0.76,3.65 ; p=0.20)$ and significant heterogeneity was observed $\left(\mathrm{I}^{2}=74 \%, P=0.02\right)$. Adult subgroup analysis included the same studies as the RCT group in long-term follow-up.

\section{Use of glaucoma medications}

The mean number of glaucoma medications was reported by three studies (558 eyes) for short-term followup and seven studies (659 eyes) for long-term follow-up. Pooled differences showed that BGI implantation lowered the number of medications by a significant value of 0.29 (95 \% CI: 0.07, 0.50; $P=0.009$ ) in short-term

Table 4 Comparison of the success rate

\begin{tabular}{|c|c|c|c|c|c|c|c|}
\hline \multirow{2}{*}{$\begin{array}{l}\text { Studies of } \\
\text { subgroups }\end{array}$} & \multirow{2}{*}{$\begin{array}{l}\text { No. of } \\
\text { studies }\end{array}$} & \multicolumn{2}{|c|}{ Crude data $(\mathrm{n} / \mathrm{N})$} & \multirow[t]{2}{*}{ OR $(95 \%$ Cl) } & \multicolumn{2}{|c|}{ Heterogeneity } & \multirow{2}{*}{$\begin{array}{l}\text { Test for ove } \\
\text { effect }(P)\end{array}$} \\
\hline & & AGV & $\mathrm{BGl}$ & & $\overline{1^{2}(\%)}$ & $P$ & \\
\hline \multicolumn{8}{|c|}{ Short-term follow-ups } \\
\hline Total & 5 & $282 / 359$ & $283 / 355$ & $0.97(0.56-1.66)$ & 42 & 0.14 & 0.90 \\
\hline Sensitivity analysis & 4 & $266 / 343$ & $271 / 339$ & $0.87(0.56-1.35)$ & 23 & 0.27 & 0.53 \\
\hline $\mathrm{RCT}$ & 2 & $205 / 263$ & 199/237 & $0.67(0.42-1.06)$ & 0 & 0.92 & 0.09 \\
\hline Non-RCT & 3 & $77 / 96$ & $84 / 118$ & $1.63(0.71-3.74)$ & 24 & 0.27 & 0.25 \\
\hline Children & 0 & / & / & / & / & / & / \\
\hline Adults & 4 & $261 / 327$ & $262 / 323$ & $1.01(0.50-2.01)$ & 56 & 0.08 & 0.99 \\
\hline \multicolumn{8}{|c|}{ Long-term follow-ups } \\
\hline Total & 7 & $219 / 370$ & $318 / 465$ & $0.73(0.54-0.99)$ & 0 & 0.44 & 0.04 \\
\hline Sensitivity analysis & 6 & $217 / 367$ & $312 / 459$ & $0.74(0.55-1.00)$ & 0 & 0.43 & 0.05 \\
\hline $\mathrm{RCT}$ & 2 & $124 / 231$ & $132 / 212$ & $0.70(0.47-1.02)$ & 0 & 0.46 & 0.07 \\
\hline Non-RCT & 5 & $95 / 139$ & $186 / 253$ & $0.82(0.45-1.48)$ & 22 & 0.28 & 0.51 \\
\hline Children & 2 & $7 / 14$ & $10 / 26$ & $0.96(0.04-21.88)$ & 64 & 0.1 & 0.98 \\
\hline Adults & 3 & $154 / 279$ & $177 / 282$ & $0.74(0.52-1.04)$ & 0 & 0.61 & 0.08 \\
\hline
\end{tabular}


Table 5 Comparison of postoperative IOP

\begin{tabular}{|c|c|c|c|c|c|c|}
\hline \multirow{2}{*}{$\begin{array}{l}\text { Studies of } \\
\text { subgroups }\end{array}$} & \multirow{2}{*}{$\begin{array}{l}\text { No. of } \\
\text { studies }\end{array}$} & \multirow{2}{*}{$\begin{array}{l}\text { No. of } \\
\text { eyes }\end{array}$} & \multirow[t]{2}{*}{ WMD (95 \% Cl) } & \multicolumn{2}{|c|}{ Heterogeneity } & \multirow{2}{*}{$\begin{array}{l}\text { Test for ove } \\
\text { effect }(P)\end{array}$} \\
\hline & & & & $\overline{I^{2}(\%)}$ & $P$ & \\
\hline \multicolumn{7}{|c|}{ Short-term follow-ups } \\
\hline Total & 6 & 685 & $2.12(0.72-3.52)$ & 49 & 0.08 & 0.003 \\
\hline Sensitivity analysis & 5 & 653 & $2.58(1.70-3.46)$ & 0 & 0.60 & 0.000 \\
\hline RCT & 2 & 477 & $2.54(1.54-3.53)$ & 0 & 0.38 & 0.000 \\
\hline Non-RCT & 4 & 208 & $1.68(-1.27-4.63)$ & 64 & 0.04 & 0.26 \\
\hline Children & 1 & 31 & $5.00(0.60-9.40)$ & / & / & 0.03 \\
\hline Adults & 3 & 509 & $1.44(-0.76-3.65)$ & 74 & 0.02 & 0.20 \\
\hline \multicolumn{7}{|c|}{ Long-term follow-ups } \\
\hline Total & 7 & 659 & $1.85(0.43-3.28)$ & 44 & 0.1 & 0.01 \\
\hline Sensitivity analysis & 6 & 651 & $1.86(0.30-3.41)$ & 53 & 0.06 & 0.02 \\
\hline $\mathrm{RCT}$ & 2 & 340 & $1.70(0.70-2.69)$ & 0 & 0.49 & 0.001 \\
\hline Non-RCT & 5 & 319 & $2.18(-0.91-5.27)$ & 60 & 0.04 & 0.17 \\
\hline Children & 3 & 85 & $3.42(0.22-6.62)$ & 0 & 0.56 & 0.04 \\
\hline Adults & Same as RCT group & & & & & \\
\hline
\end{tabular}

follow-up (Fig. 6) and 0.42 (95 \% CI: 0.22, 0.62; $P<0.05)$ in long-term follow-up (Fig. 7). Sensitivity analysis and RCT subgroup analysis showed a significant difference in the mean number of glaucoma medications between the BGI and AGV groups in long-and short-term followup (Table 6). The random-effect model was used for pooling. One retrospective study (81 eyes) reported that medication use was not significantly different between the BGI and AGV groups. For the long-term follow-up, the pooled results of the non-RCT subgroups were consistent with the total group. No significant difference in use of glaucoma medication between the BGI and AGV groups was observed in the children subgroup ( 3 studies, 85 eyes). The WMD was 0.20 ( $95 \% \mathrm{CI}$ : -0.40 , $0.80, P=0.51$ ). Adult subgroup analysis included the same studies as the RCT subgroup. The heterogeneity test showed a lack of significant heterogeneity for the total, subgroup, and sensitivity analyses.

\section{Postoperative complications}

A total of 971 eyes (443 in the AGV group and 528 in the BGI group) were included in analysis of complications. Because Budenz et al. reported early ( $\leq 3$ months) complications [21] and late ( $>3$ months) complications [22], the latter category was used in the pooled calculations. The definition of severe complications was the same as that in the original studies, including severe complications and devastating complications. If the studies did not report numbers of severe or devastating complications, we included the following complications for pooling: suprachoroidal hemorrhage, severe choroidal effusion (requiring correctional surgery), retinal detachment, endophthalmitis, and vitreous hemorrhage. A total of 158 eyes in the AGV group and 199 eyes in the BGI group experienced complications. Eyes in the AGV group experienced a significantly lower overall occurrence of complications than those in the BGI group

\begin{tabular}{|c|c|c|c|c|c|c|c|c|c|c|c|c|}
\hline \multirow{2}{*}{ Study or Subgroup } & Mean & AGV & \multicolumn{3}{|c|}{ BGI } & Total & Weight & $\begin{array}{l}\text { Mean Difference } \\
\text { IV. Random, } 95 \% \mathrm{Cl}\end{array}$ & \multicolumn{4}{|c|}{$\begin{array}{c}\text { Mean Difference } \\
\text { IV. Random, } 95 \% \mathrm{CI}\end{array}$} \\
\hline & 15.4 & 5.5 & 132 & 13.4 & 6.9 & 117 & $25.8 \%$ & $2.00[0.44,3.56]$ & & & $-=$ & \\
\hline Christakis & 16.5 & 5.3 & 120 & 13.6 & 4.6 & 108 & $28.8 \%$ & $2.90[1.61,4.19]$ & & & $=$ & \\
\hline Chung & 13.7 & 4 & 16 & 16.8 & 7.3 & 16 & $9.0 \%$ & $-3.10[-7.18,0.98]$ & & & & \\
\hline El Gendy & 24 & 5.4 & 11 & 19 & 6.9 & 20 & $8.0 \%$ & $5.00[0.60,9.40]$ & & & 一 & \\
\hline Goulet & 18 & 6.2 & 19 & 14.7 & 6.8 & 62 & $12.4 \%$ & $3.30[0.04,6.56]$ & & & 一- & \\
\hline Syed & 13.6 & 5.6 & 32 & 12.1 & 5.3 & 32 & $16.0 \%$ & $1.50[-1.17,4.17]$ & & & $f-$ & \\
\hline Total $(95 \% \mathrm{Cl})$ & & & 330 & & & 355 & $100.0 \%$ & $2.12[0.72,3.52]$ & & & $\gamma$ & \\
\hline $\begin{array}{l}\text { Heterogeneity: } \mathrm{Tau}^{2}= \\
\text { Test for overall effect }\end{array}$ & $\begin{array}{l}1.34 ; C l \\
Z=2.97\end{array}$ & $\begin{array}{l}\mathrm{i}^{2}= \\
(\mathrm{P}=\end{array}$ & $\begin{array}{l}9.86, d f \\
0.003)\end{array}$ & $=5(P$ & $=0.0$ & $8) ; 1^{2}=$ & $49 \%$ & & -20 & $\begin{array}{r}-10 \\
A\end{array}$ & $\mathrm{~V}_{\mathrm{BGI}} 10$ & 20 \\
\hline
\end{tabular}




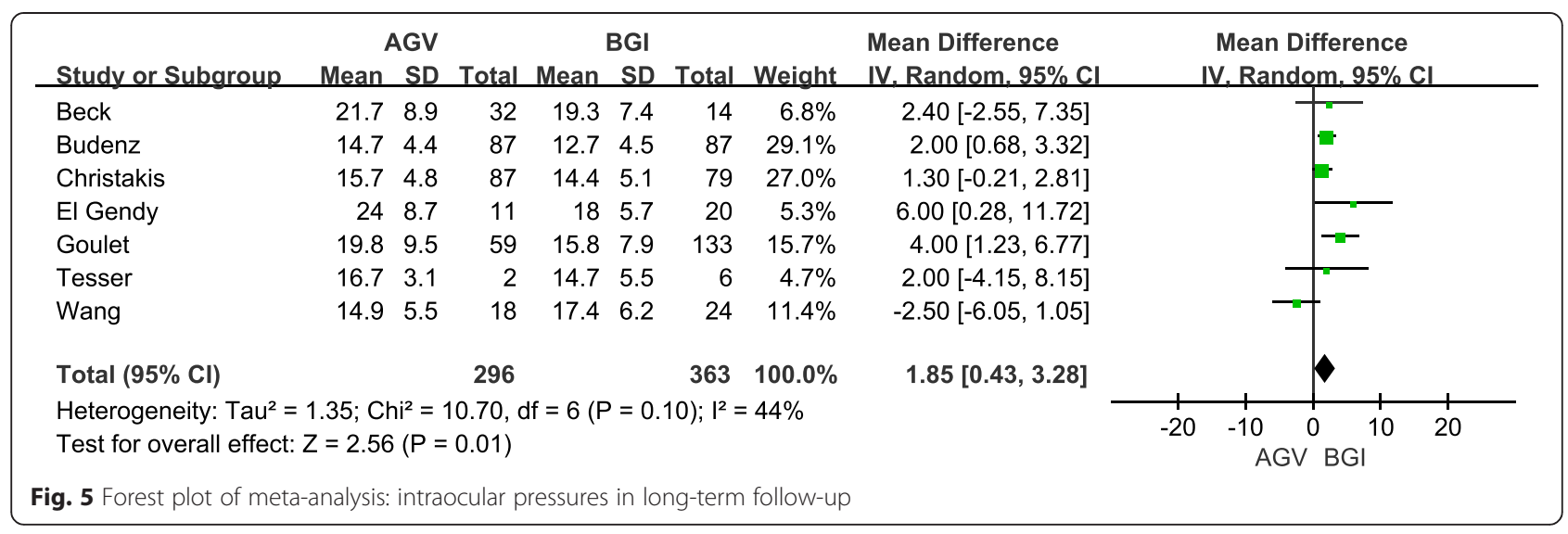

(OR, 0.67; 95 \% CI: 0.50, 0.90; $P=0.007$ ) and no heterogeneity was identified $\left(\mathrm{I}^{2}=0 \%, P=0.88\right)$. The occurrence of severe complications in the AGV group was also lower than that in the BGI group (OR: 0.57; $95 \%$ CI: $0.36,0.91, P=0.02$ ). The AGV group was characterized by a lower incidence of hypotony, but this difference was not statistically significant (6 studies, 724 eyes; OR: $0.54 ; 95 \% \mathrm{CI}: 0.26,1.11 ; P=0.1$ ). There were no significant differences in hyphema, choroidal effusion, and tube complications (including tube obstruction, malposition, and erosion) between the two groups. The results of sensitivity analysis were consistent with the total groups (included all eligible studies). The incidence of complications in both groups is listed in Table 7.

Begg's test and funnel plots were used to assess publication bias in pooled effect sizes that calculated using five or more studies. Publication bias assessment showed no significant bias in success rates, IOP, and glaucoma medications in long-term follow-up, overall and severe complications, hypotony, and choroidal effusion (all $P \geq 0.05$ ).

We used GRADEpro 3.6 software to assess the quality of evidence for each outcome in the total groups (Table 8). Because data from RCTs and nonRCTs were included in the analysis, we used the standards of an observational study to assess overall outcomes. The pooled IOP and risk of tube complications were identified significant heterogeneity; therefore we graded it as "inconsistency". We downgraded outcomes of tube complications, IOP in short-and long-term as "very low" quality. The rest of the outcomes were graded "low" quality.

\section{Discussion}

A total of 10 studies were included in this meta-analysis. Two of these studies were RCTs and eight were nonRCTs. The pooled results showed no statistically significant difference in success rates between the AGV and BGI groups for short-term follow-up. The success rates for the AGV group were lower than for the BGI group for long-term follow-up, but sensitivity and subgroup analyses showed a lack of stability. Nonetheless, the BGI group had better efficacy in controlling IOP than the AGV group. The pooled results from the RCT subgroup support the point that better efficacy in the BGI group, but the non-RCT subgroup showed negative results with significant heterogeneity. The BGI group required fewer glaucoma medications than the AGV group. More reoperations for glaucoma were required in the AGV group than in the BGI group. With regard to safety, the AGV was associated with a significantly lower overall frequency of adverse events and incidence of severe complications than the BGI. In subgroup analysis based on age, all of the

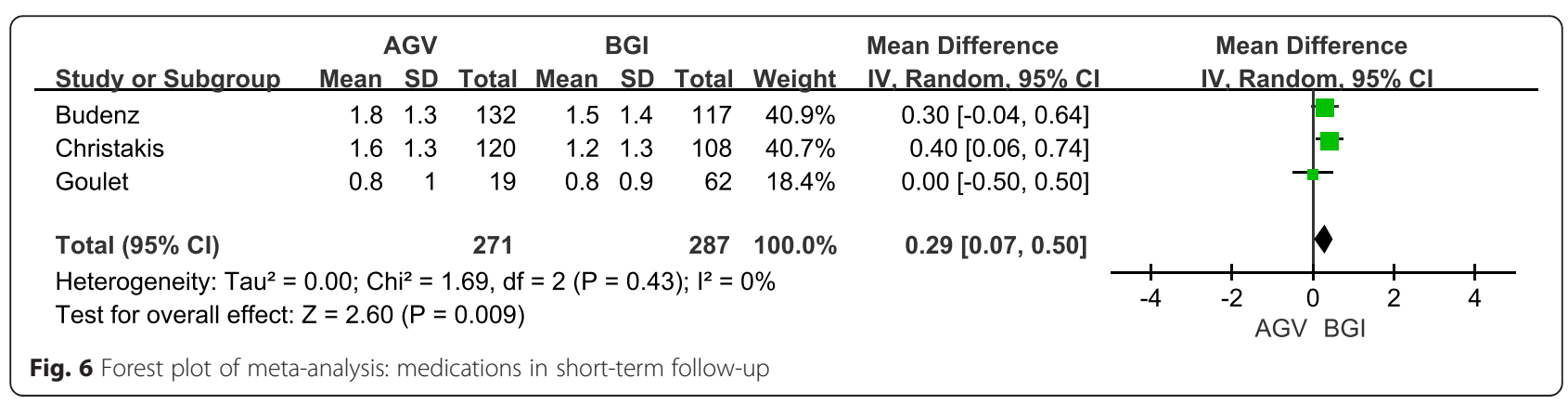




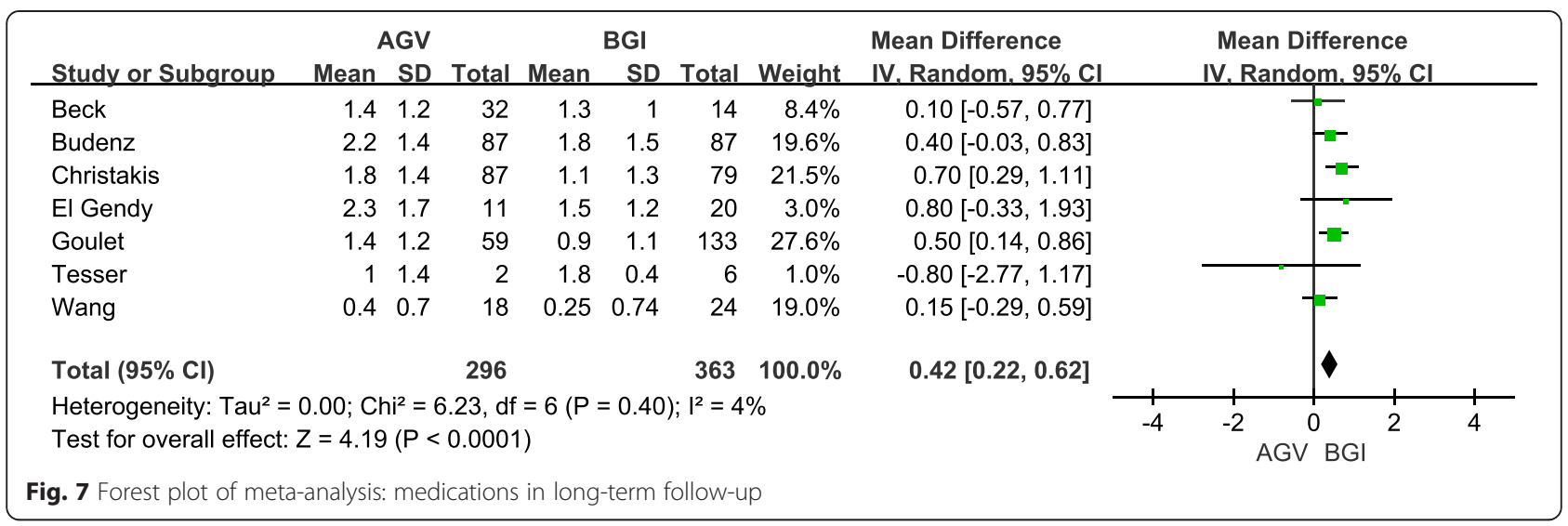

studies that were included in children subgroup analyses were retrospective studies and sample sizes were small. More well-designed studies with a larger sample size needed to be performed in children. Publication bias and heterogeneity testing indicated that the pooled results were valid.

Although both implantations shared a similar success rate, the BGI resulted in a lower level of postoperative IOP and use of glaucoma medications than the AGV. The major success criteria, upper limit of IOP, ranged from 21 to $24 \mathrm{mmHg}$. However, the Advanced Glaucoma Intervention Study showed that an IOP target of greater than $18 \mathrm{mmHg}$ may be insufficient to prevent progression of visual field defects [23]. Therefore, when setting a strict IOP target, the BGI may be more advantageous than the AGV. A larger surface area of the end plate for the Baerveldt implant $\left(350 \mathrm{~mm}^{2}\right.$ or $\left.250 \mathrm{~mm}^{2}\right)$ compared with the Ahmed valve $\left(184 \mathrm{~mm}^{2}\right)$ would theoretically help aqueous humor reabsorption into the circulation. Previous studies compared the efficacy of IOP control in several GDIs with different surface areas. They showed that the double-plate Molteno implant (surface area $=268 \mathrm{~mm}^{2}$ ) was superior to the singleplate implant [24]. The $350-\mathrm{mm}^{2}$ Baerveldt implant was more successful than the $500-\mathrm{mm}^{2}$ implant for overall IOP control [25]. These studies suggested that IOP control may be nonlinear relative to the surface area of the end plate. Although the AGV is equipped with a valve to reduce the occurrence of postoperative complications, the resistance to aqueous humor outflow eventually becomes counterproductive [26].

The models of the Ahmed valve and Baerveldt implant in our study were not consistent. Old polypropylene models (S2 and S3) and new silicone models (FP7) of the Ahmed valve were tested. Whether differences in biomaterial and end plate rigidity added an additional

Table 6 Using of medication in comparing AGV with BGl

\begin{tabular}{|c|c|c|c|c|c|c|}
\hline \multirow{2}{*}{$\begin{array}{l}\text { Studies of } \\
\text { subgroups }\end{array}$} & \multirow{2}{*}{$\begin{array}{l}\text { No. of } \\
\text { studies }\end{array}$} & \multirow{2}{*}{$\begin{array}{l}\text { No. of } \\
\text { eyes }\end{array}$} & \multirow[t]{2}{*}{ WMD (95 \% Cl) } & \multicolumn{2}{|c|}{ Heterogeneity } & \multirow{2}{*}{$\begin{array}{l}\text { Test for ove } \\
\text { effect }(P)\end{array}$} \\
\hline & & & & $\mathrm{I}^{2}(\%)$ & $P$ & \\
\hline \multicolumn{7}{|c|}{ Short-term follow-ups } \\
\hline Total & 3 & 558 & $0.29(0.07-0.50)$ & 0 & 0.43 & 0.009 \\
\hline $\mathrm{RCT}$ & 2 & 477 & $0.35(0.11-0.59)$ & 0 & 0.68 & 0.004 \\
\hline Non-RCT & 1 & 81 & $0.00(-0.50-0.50)$ & / & / & 1 \\
\hline Children & 0 & / & / & / & / & / \\
\hline Adults & \multicolumn{6}{|c|}{ Same as RCT group } \\
\hline \multicolumn{7}{|c|}{ Long-term follow-ups } \\
\hline Total & 7 & 659 & $0.42(0.22-0.62)$ & 4 & 0.40 & 0.000 \\
\hline Sensitivity analysis & 6 & 651 & $0.43(0.24-0.62)$ & 0 & 0.45 & 0.000 \\
\hline RCT & 2 & 340 & $0.56(0.26-0.85)$ & 0 & 0.32 & 0.000 \\
\hline Non-RCT & 5 & 319 & $0.33(0.08-0.57)$ & 0 & 0.42 & 0.01 \\
\hline Children & 3 & 85 & $0.20(-0.40-0.80)$ & 7 & 0.34 & 0.51 \\
\hline Adults & \multicolumn{6}{|c|}{ Same as RCT group } \\
\hline
\end{tabular}


Table 7 Risk of complications in comparing AGV with BGl

\begin{tabular}{|c|c|c|c|c|c|c|c|}
\hline \multirow[t]{2}{*}{ Complications } & \multirow{2}{*}{$\begin{array}{l}\text { No. of } \\
\text { studies }\end{array}$} & \multicolumn{2}{|c|}{ Crude data $(\mathrm{n} / \mathrm{N})$} & \multirow[t]{2}{*}{ OR $(95 \% \mathrm{Cl})$} & \multicolumn{2}{|c|}{ Heterogeneity } & \multirow{2}{*}{$\begin{array}{l}\text { Test for over } \\
\text { effect }(P)\end{array}$} \\
\hline & & AGV & BGl & & $\overline{1^{2}(\%)}$ & $P$ & \\
\hline Total (eyes) & 8 & $158 / 443$ & 199/528 & $0.67(0.50,0.90)$ & 0 & 0.88 & 0.007 \\
\hline Severe complication (cases) & 8 & $34 / 443$ & $58 / 528$ & $0.57(0.36,0.91)$ & 0 & 0.83 & 0.02 \\
\hline Hypotony (cases) & 6 & $18 / 316$ & $34 / 408$ & $0.54(0.26,1.11)$ & 5 & 0.38 & 0.1 \\
\hline Tube complication (cases) & 4 & $28 / 317$ & $40 / 303$ & $0.68(0.25,1.87)$ & 56 & 0.08 & 0.46 \\
\hline Hyphema (cases) & 4 & $23 / 317$ & $33 / 303$ & $0.64(0.36,1.13)$ & 0 & 0.58 & 0.12 \\
\hline Choroidal effusion (cases) & 5 & $40 / 336$ & $38 / 357$ & $1.10(0.72,1.69)$ & 0 & 0.62 & 0.66 \\
\hline
\end{tabular}

Table 8 Summary of AGV compared to BGl for glaucoma

\begin{tabular}{|c|c|c|c|c|c|}
\hline \multirow[t]{2}{*}{ Outcomes } & \multirow{2}{*}{$\begin{array}{l}\text { No of participants } \\
\text { (studies) follow up }\end{array}$} & \multirow{2}{*}{$\begin{array}{l}\text { Quality of the } \\
\text { evidence (GRADE) }\end{array}$} & \multirow{2}{*}{$\begin{array}{l}\text { Relative effect } \\
(95 \% \mathrm{Cl})\end{array}$} & \multicolumn{2}{|c|}{ Anticipated absolute effects } \\
\hline & & & & Risk with $\mathrm{BGl}$ & Risk difference with AGV (95 \% Cl) \\
\hline IOP (short-term) & $\begin{array}{l}685 \text { (6 studies) } \\
12 \text { months }\end{array}$ & $\begin{array}{l}\oplus \Theta \Theta \Theta \text { VERY LOW } \\
\text { due to inconsistency }\end{array}$ & & & $\begin{array}{l}\text { The mean iop (short-term) in the } \\
\text { intervention groups was } 2.12 \\
\text { higher ( } 0.72 \text { to } 3.52 \text { higher) }\end{array}$ \\
\hline IOP (long-term) & $\begin{array}{l}659 \text { (7 studies) } \\
20 \text { to } 60 \text { months }\end{array}$ & $\begin{array}{l}\oplus \ominus \ominus \ominus \text { VERY LOW } \\
\text { due to inconsistency }\end{array}$ & & & $\begin{array}{l}\text { The mean iop (long-term) in the } \\
\text { intervention groups was } 1.85 \text { highe } \\
\text { ( } 0.43 \text { to } 3.28 \text { higher) }\end{array}$ \\
\hline Success rate (short-term) & $\begin{array}{l}714 \text { ( } 5 \text { studies) } \\
12 \text { months }\end{array}$ & $\oplus \oplus \ominus \ominus \mathrm{LOW}$ & OR 0.97 (0.56 to 1.66) & 797 per 1000 & $\begin{array}{l}5 \text { fewer per } 1000 \\
\text { (from } 110 \text { fewer to } 70 \text { more) }\end{array}$ \\
\hline Success rate (long-term) & $\begin{array}{l}835 \text { (7 studies) } \\
20 \text { to } 60 \text { months }\end{array}$ & $\oplus \oplus \ominus \ominus \mathrm{LOW}$ & OR 0.73 (0.54 to 0.99$)$ & 684 per 1000 & $\begin{array}{l}72 \text { fewer per } 1000 \\
\text { (from } 2 \text { fewer to } 145 \text { fewer) }\end{array}$ \\
\hline Medication (short-term) & \multirow{2}{*}{$\begin{array}{l}558 \text { (3 studies) } \\
12 \text { months }\end{array}$} & \multirow[t]{2}{*}{$\oplus \oplus \ominus \ominus \mathrm{LOW}$} & & & \multirow{2}{*}{$\begin{array}{l}\text { The mean medication (short-term) } \\
\text { in the intervention groups was } \\
0.29 \text { higher ( } 0.07 \text { to } 0.5 \text { higher) }\end{array}$} \\
\hline Scale from: 0 to 5. & & & & & \\
\hline Medication (long-term) & \multirow{2}{*}{$\begin{array}{l}659 \text { (7 studies) } \\
20 \text { to } 60 \text { months }\end{array}$} & \multirow[t]{2}{*}{$\oplus \oplus \ominus \ominus \mathrm{LOW}$} & & & \multirow{2}{*}{$\begin{array}{l}\text { The mean medication (long-term) } \\
\text { in the intervention groups was } \\
0.42 \text { higher ( } 0.22 \text { to } 0.62 \text { higher) }\end{array}$} \\
\hline Scale from: 0 to 5. & & & & & \\
\hline Total complications & $\begin{array}{l}971 \text { ( } 8 \text { studies) } \\
1 \text { to } 3 \text { years }\end{array}$ & $\oplus \oplus \ominus \ominus \mathrm{LOW}$ & OR 0.67 (0.5 to 0.9 ) & 377 per 1000 & $\begin{array}{l}89 \text { fewer per } 1000 \\
\text { (from } 24 \text { fewer to } 145 \text { fewer) }\end{array}$ \\
\hline Servere complications & $\begin{array}{l}971 \text { ( } 8 \text { studies) } \\
1 \text { to } 3 \text { years }\end{array}$ & $\oplus \oplus \ominus \ominus \mathrm{LOW}$ & OR 0.57 (0.36 to 0.91$)$ & 110 per 1000 & $\begin{array}{l}44 \text { fewer per } 1000 \\
\text { (from } 9 \text { fewer to } 67 \text { fewer) }\end{array}$ \\
\hline Reoperation for glaucoma & $\begin{array}{l}632 \text { ( } 3 \text { studies) } \\
3 \text { to } 5 \text { years }\end{array}$ & $\oplus \oplus \ominus \ominus \mathrm{LOW}$ & OR 2.7 (1.54 to 4.74$)$ & 60 per 1000 & $\begin{array}{l}87 \text { more per } 1000 \\
\text { (from } 29 \text { more to } 172 \text { more) }\end{array}$ \\
\hline Hypotony & $\begin{array}{l}724 \text { ( } 6 \text { studies) } \\
1 \text { to } 3 \text { years }\end{array}$ & $\oplus \oplus \ominus \ominus$ LOW & OR 0.54 (0.26 to 1.11$)$ & 83 per 1000 & $\begin{array}{l}37 \text { fewer per } 1000 \\
\text { (from } 60 \text { fewer to } 8 \text { more) }\end{array}$ \\
\hline Tube complications & $\begin{array}{l}620 \text { ( } 4 \text { studies) } \\
1 \text { to } 3 \text { years }\end{array}$ & $\begin{array}{l}\oplus \Theta \Theta \Theta \text { VERY LOW } \\
\text { due to inconsistency }\end{array}$ & OR 0.68 (0.25 to 1.87$)$ & 132 per 1000 & $\begin{array}{l}38 \text { fewer per } 1000 \\
\text { (from } 95 \text { fewer to } 89 \text { more) }\end{array}$ \\
\hline Hyphema & $\begin{array}{l}620 \text { ( } 4 \text { studies) } \\
1 \text { to } 3 \text { years }\end{array}$ & $\oplus \oplus \ominus \ominus \mathrm{LOW}$ & OR 0.64 (0.36 to 1.13$)$ & 109 per 1000 & $\begin{array}{l}36 \text { fewer per } 1000 \\
\text { (from } 67 \text { fewer to } 12 \text { more) }\end{array}$ \\
\hline Choroidal effusion & $\begin{array}{l}693 \text { (5 studies) } \\
13 \text { to } 36 \text { months }\end{array}$ & $\oplus \oplus \ominus \ominus \mathrm{LOW}$ & OR 1.1 (0.72 to 1.69 ) & 106 per 1000 & $\begin{array}{l}11 \text { more per } 1000 \\
\text { (from } 30 \text { fewer to } 73 \text { more) }\end{array}$ \\
\hline
\end{tabular}

Cl: Confidence interval; RR: Risk ratio; OR: Odds ratio

GRADE Working Group grades of evidence

High quality: Further research is very unlikely to change our confidence in the estimate of effect

Moderate quality: Further research is likely to have an important impact on our confidence in the estimate of effect and may change the estimate

Low quality: Further research is very likely to have an important impact on our confidence in the estimate of effect and is likely to change the estimate

Very low quality: We are very uncertain about the estimate

${ }^{1}$ Significant heterogeneity was observed $(P=0.08)$

${ }^{2}$ Significant heterogeneity was observed $(P=0.1)$

${ }^{3}$ Significant heterogeneity identified $(p=0.08)$ 
contribution to long-term IOP results was still uncertain, but the silicone model was associated with a lower incidence of complications [27-30]. Our study included the $350-\mathrm{mm}^{2}$ model and the $250-\mathrm{mm}^{2}$ model of BGIs, and both were made of silicone. Previous studies showed that these two models shared similar success rates and occurrence of complications [15, 31]. Despite the controversial effects of characteristics of the implant, potential heterogeneity from inconsistencies in the models could weaken the pooled results.

Begg's test and funnel plots were used to assess publication bias. We found no significant bias. However, the results of the funnel plots may not be statistically meaningful because of the lack of power for the small sample size.

To minimize heterogeneity due to the inconsistencies of follow-up times, we pooled data for two time periods. Implantations concurrent with lens-related surgeries were enrolled in this meta-analysis. Phacoemulsification and extracapsular cataract removal can reduce IOP [32, 33], especially in patients with a shallow anterior chamber. However, the effects of these procedures combined with glaucoma implantation devices were uncertain. In addition, extra surgical procedures could lead to a higher risk of adverse events. Despite this heterogeneity, we included these two articles because they provided important clinical information. Furthermore, sensitivity analysis was performed to examine the heterogeneity.

There are some limitations to our study. First, only two RCTs were included in the studies. Most studies were retrospective comparative studies that had a potential selection bias. A small sample size and incomplete baseline data also weakened the validity of the tests. Second, surgical success and complication criteria were not standardized among the included studies. Therefore, standardized assessment criteria should be established in further studies. Third, our current statistical methodology assumed that the input samples were approximately symmetric and approximately followed a Gaussian distribution. However, the values of glaucoma medications are non-negative integers, mostly in the range of 1 to 4 , which are more likely to have a skewed distribution. Skewed distributions tend to have larger SD than mean. This over-generalized assumption may result in biased conclusion. Fourth, we did not analyze visual outcomes as a result of inconsistent statistical methods used in the visual results. Furthermore, we did not perform subgroup analyses for types of glaucoma and race.

When choosing a device, other factors should also be considered, for example, the experience of the surgeon, compliance during follow-up, and the goals for therapy. Moreover, additional RCTs with a longer duration and a larger sample size are required to better determine the efficacy and safety of the AGV and BGI for the treatment of glaucoma.

\section{Conclusions}

This study showed no significant difference in the success rate between the BGI and AGV groups. The BGI performed better in the control of IOP and required fewer medications than the AGV. The AGV performed better than the BGI regarding safety.

\section{Additional files}

\section{Additional file 1: Search strategy.doc, search strategy for meta-} analysis. (DOCX 16 kb)

Additional file 2: PRISMA 2009 Checklist.doc, PRISMA Checklist for meta-analysis. (DOC $62 \mathrm{~kb}$ )

\section{Abbreviations}

AGV: Ahmed glaucoma valve; BGl: Baerveldt glaucoma implant; Cl: Confidence interval; GDI: Glaucoma drainage implant; GRADE: Grading of recommendations assessment, development and evaluation; IOL: Intraocular lens; IOP: Intraocular pressure; non-RCT: Non-randomized controlled clinical trial; OR: Odds ratio; RCT: Randomized controlled clinical trial;

WMD: Weighted mean difference.

\section{Competing interests}

The authors declare that they have no competing interests.

\section{Authors' contributions}

YW and XX contributed to the study concept and design and drafted the manuscript. PW and CZ contributed to data collection and analysis. YW wrote the first draft of the manuscript. XX reviewed and revised the manuscript, and produced the final version. All authors contributed to the interpretation of the data and critically reviewed the manuscript. All authors read and approved the final manuscript.

\section{Availability of data and materials}

Not applicable.

Authors' information

Not applicable.

\section{Acknowledgements}

This research was supported by the Fundamental Research Funds for the Central Universities of Central South University (No. 2014zzts349).

\section{Author details}

${ }^{1}$ Department of Ophthalmology, Xiangya Hospital, Central South University, \#87 Xiangya Road, Changsha, Hunan 410008, China. ${ }^{2}$ Department of Orthopaedics, Xiangya Hospital, Central South University, Changsha, Hunan Province, China.

Received: 8 May 2015 Accepted: 18 September 2015

Published online: 13 October 2015

\section{References}

1. Allen RC, Bellows AR, Hutchinson RT, Murphy SD. Filtration surgery in the treatment of neovascular glaucoma. Ophthalmology. 1982;89:1181-9.

2. Gedde SJ, Schiffman JC, Feuer WJ, Herndon LW, Brandt JD, Budenz DL. Treatment outcomes in the Tube Versus Trabeculectomy (TVT) Study after five years of follow-up. Am J Ophthalmol. 2012;153:789-803.

3. Molteno ACB. New implant for drainage in glaucoma clinical trial. Br J Ophthalmol. 1969;53:606-15.

4. Francis BA, Cortes A, Chen J, Alvarado JA. Characteristics of glaucoma drainage implants during dynamic and teady-state flow conditions. Ophthalmology. 1998;105:1708-14.

5. Huang MC, Netland PA, Coleman AL, Siegner SW, Moster MR, Hill RA. Intermediate-term clinical experience with the Ahmed Glaucoma Valve implant. Am J Ophthalmol. 1999;127:27-33. 
6. Patel S, Pasquale LR. Glaucoma drainage devices: a review of the past, present, and future. Semin Ophthalmol. 2010;25:265-70.

7. Budenz DL, Barton K, Gedde SJ, Feuer WJ, Schiffman J, Costa VP, et al. Five-year treatment outcomes in the Ahmed Baerveldt comparison study. Ophthalmology. 2015;122:308-16

8. Higgins J, Green S. Cochrane Handbook for Systematic Reviews of Interventions. Version 5.1.0 (updated March 2011). Cochrane Collaboration 2011. Available from:www.cochrane-handbook.org. Accessed Feb 05, 2015

9. Liu JP. Method of systematic reviews in nonrandomized study (1). Chinese J Evid Based Med. 2001:1:239-43.

10. Guyatt G, Oxman AD, Akl EA, Kunz R, Vist G, Brozek J, et al. GRADE guidelines: 1. Introduction-GRADE evidence profiles and summary of findings tables. J Clin Epidemiol. 2011;64:383-94.

11. Begg CB, Mazumdar M. Operating characteristics of a rank correlation test for publication bias. Biometrics. 1994;50:1088-101.

12. Christakis PG, Tsai JC, Kalenak JW, Zurakowski D, Cantor LB, Kammer JA, et al. The Ahmed versus Baerveldt study: three-year treatment outcomes. Ophthalmology. 2013;120:2232-40.

13. El Gendy NM, Song JC. Long term comparison between single stage Baerveldt and Ahmed glaucoma implants in pediatric glaucoma. Saudi J Ophthalmol. 2012;26:323-6.

14. Goulet 3rd RJ, Phan AD, Cantor LB, WuDunn D. Efficacy of the Ahmed S2 glaucoma valve compared with the Baerveldt 250-mm2 glaucoma implant. Ophthalmology. 2008;115:1141-7.

15. Tsai JC, Johnson CC, Kammer JA, Dietrich MS. The Ahmed shunt versus the Baerveldt shunt for refractory glaucoma II: longer-term outcomes from a single surgeon. Ophthalmology. 2006;113:913-7.

16. Tesser R, Hess DB, Freedman SF. Combined intraocular lens implantation and glaucoma implant (tube shunt) surgery in pediatric patients: a case series. JAAPOS. 2005;9:330-5.

17. Chung AN, Aung T, Wang JC, Chew PT. Surgical outcomes of combined phacoemulsification and glaucoma drainage implant surgery for Asian patients with refractory glaucoma with cataract. Am J Ophthalmol. 2004;137:294-300.

18. Syed HM, Law SK, Nam SH, Li G, Caprioli J, Coleman A. Baerveldt-350 implant versus Ahmed valve for refractory glaucoma: a case-controlled comparison. J Glaucoma. 2004;13:38-45.

19. Wang JC, See JL, Chew PT. Experience with the use of Baerveldt and Ahmed glaucoma drainage implants in an Asian population. Ophthalmology. 2004;111:1383-8.

20. Beck AD, Freedman S, Kammer J, Jin J. Aqueous shunt devices compared with trabeculectomy with Mitomycin-C for children in the first two years of life. Am J Ophthalmol. 2003;136:994-1000.

21. Budenz DL, Barton K, Feuer WJ, Schiffman J, Costa VP, Godfrey DG, et al Treatment outcomes in the Ahmed Baerveldt Comparison Study after 1 year of follow-up. Ophthalmology. 2011;118:443-52.

22. Barton K, Feuer WJ, Budenz DL, Schiffman J, Costa VP, Godfrey DG, et al. Three-year treatment outcomes in the Ahmed Baerveldt comparison study. Ophthalmology. 2014;121:1547-57. e1.

23. The Advanced Glaucoma Intervention Study (AGIS) Investigators. The Advanced Glaucoma Intervention Study (AGIS): 7. The relationship between control of intraocular pressure and visual field deterioration. Am J Ophthalmol. 2000;130:429-40.

24. Heuer DK, Lloyd MA, Abrams DA, Baerveldt G, Minckler DS, Lee MB, et al Which is better? One or two? A randomized clinical trial of single-plate versus double-plate Molteno implantation for glaucomas in aphakia and pseudophakia. Ophthalmology. 1992;99:1512-9.

25. Britt MT, LaBree LD, Lloyd MA, Minckler DS, Heuer DK, Baerveldt G, et al. Randomized clinical trial of the $350-\mathrm{mm} 2$ versus the $500-\mathrm{mm} 2$ Baerveldt implant: longer term results: is bigger better? Ophthalmology. 1999;106:2312-8.

26. Pan T, Stay MS, Barocas VH, Brown JD, Ziaie B. Modeling and characterization of a valved glaucoma drainage device with implications for enhanced therapeutic efficacy. IEEE Trans Biomed Eng. 2005;52:948-51.

27. Mackenzie PJ, Schertzer RM, Isbister CM. Comparison of silicone and polypropylene Ahmed glaucoma valves: two-year follow-up. Can Ophthalmol. 2007;42:227-32.

28. Law SK, Nguyen A, Coleman AL, Caprioli J. Comparison of safety and efficacy between silicone and polypropylene Ahmed glaucoma valves in refractory glaucoma. Ophthalmology. 2005;112:1514-20.
29. Brasil MV, Rockwood EJ, Smith SD. Comparison of silicone and polypropylene Ahmed Glaucoma Valve implants. J Glaucoma. 2007;16:36-41.

30. Ishida K, Netland PA, Costa VP, Shiroma L, Khan B, Ahmed II. Comparison of polypropylene and silicone Ahmed Glaucoma Valves. Ophthalmology. 2006;113:1320-6.

31. Allan EJ, Khaimi MA, Jones JM, Ding K, Skuta GL. Long-term efficacy of the Baerveldt $250 \mathrm{~mm} 2$ compared with the Baerveldt $350 \mathrm{~mm} 2 \mathrm{implant}$ Ophthalmology. 2015;122:486-93

32. Brown RH, Zhong L, Whitman AL, Lynch MG, Kilgo PD, Hovis KL. Reduced intraocular pressure after cataract surgery in patients with narrow angles and chronic angle-closure glaucoma. J Cataract Refract Surg. 2014;40:1610-4.

33. Shingleton BJ, Gamell LS, O'Donoghue MW, Baylus SL, King R. Long-term changes in intraocular pressure after clear corneal phacoemulsification: normal patients versus glaucoma suspect and glaucoma patients. J Cataract Refract Surg. 1999;25:885-90.

\section{Submit your next manuscript to BioMed Central and take full advantage of:}

- Convenient online submission

- Thorough peer review

- No space constraints or color figure charges

- Immediate publication on acceptance

- Inclusion in PubMed, CAS, Scopus and Google Scholar

- Research which is freely available for redistribution 